\title{
Üniversite Öğrencilerinde Terör Mağduru Olma Korkusunun Değerlendirilmesi: İstanbul Örneği
}

\author{
DOI: 10.26466/opus.503138 \\ * \\ Burcu Türk ${ }^{*}$ Nurcan Hamzaoğlu** \\ *Dr. Öğr. Üyesi., Haliç Üniversitesi, Psikoloji Bölümü, İstanbul / Türkiye \\ E-Posta: turk burcu@hotmail.com \\ ORCID: 0000-0003-3290-5886 \\ ** Dr. Öğr. Üy., Yeni Yüzyıl Üniversitesi, Sağlık Bilimleri Enstitüsü \\ E-Posta: nurcan.hamzaoglu@yeniyuzyil.edu.tr ORCID: 0000-0002-8471-0442
}

\section{Öz}

Terör kişilerin yaşam hakkını ve güvenliğini tehdit eden çok yönlü bir eylemdir. Özellikle belirli bir yerinin ya da belirli bir zamanının olmaması, terörizmin insanlar üzerinde yarattığı dehşetin derecesini daha da artırmaktadır Uluslarası bir tehdit olan terörün fiziksel tahribatının yanında psikolojik ve sosyolojik etkisinin de incelenmesi gerektiği bir ihtiyaç olarak karşımıza çıkmaktadır. Terör mağduru olma korkusu düzeylerinin saptanması amacıyla 276 üniversite öğrencisine anket uygulanmıştır. Çalışmaya katılanları \%71,4'ü kadın, \%28,6'sı erkektir. Katılımcıların \% 87,7'si yaşanan terör olaylarının gündelik yaşantılarma olumsuz etkisi olduğunu düşünmektedir. Yaşanan terör olayları nedeniyle ülkenin geleceği konusunda endişeli olduğunu belirtenlerin oranı \% 85,2 olup sadece güvenlik nedeniyle ülkeye taşınmayı düşünenlerin oranının \% 63,5 olduğu görülmektedir. Katılımcıların \%72,8'i kendisinin, $\% 75,4$ 'ü yakınlarının terör eylemi mă̆gduru olacă̆̆ endişesi yaşadığını ifade etmektedir. Terör mağduru olma korkusu, evrensel düzeyde, yaşamı etkileyen bireysel ve toplumsal önemli bir sorundur. Çalışmanın sonuçları, mağdur olma korkusu kapsamında terörü ele almış olması ve uluslarası bir tehdit olan terörün psikolojik ve sosyolojik etkilerini incelemesi açısından önemlidir.

Anahtar Kelimeler: Terör, Suç korkusu, Mă̆dur olma korkusu, Mağdur olma endişesi 


\title{
The Evaluation of The Fear of Being Victims of Terror at University Students: The Example of Istanbul
}

\begin{abstract}
Terror is a multi-faceted action that threatens the right to life and security of persons. Especially the fact that it does not have a specific place or time, further increases the degree of horror that terrorism creates on people. In addition to the physical destruction of terror, which is an international threat, psychological and sociological effects of it must be examined. A questionnaire was applied to 276 university students in order to determine the level of the fear of being a victim of terror. $71.4 \%$ of the participants were female and $28.6 \%$ were male. $87.7 \%$ of the participants think that the terrorist events have a negative effect on their daily lives. The ratio of those who stated that they are worried about the future of the country due to the terrorist incidents is $85.2 \%$ and the rate of those who think about moving to another country for security reasons is $63.5 \%$. The rate of those who stated that they have worries about themselves being a victim of terrorist acts was $72.8 \%$ and their relatives being a victim was $75.4 \%$. The fear of being a victim of terror is an important individual and social problem that influences lives on a universal level. The results of the study are important in terms of addressing terror within the context of the fear of being victims and examining the psychological and sociological effects of it, which is an international threat.
\end{abstract}

Keywords: Terror, Fear of crime, Fear of being a victim, Worry about being a victim 


\section{Giriş}

Suç korkusu modern toplumlarda en önemli toplumsal sorunlar arasında yer almaya başlamıştır. Başta suç olmak üzere toplumsal düzeni bozan eylemlere yönelik tepkiler ve tartışmalar artık kültürel ve siyasal yaşamın önemli konuları arasındadır. Toplumlar modernleştikçe suç mağduru olma endişesi de beraberinde artmaktadır. Formel toplumsal denetim kurumlarının yetersizliği, enformel toplumsal denetimin modern kentlerde azalması, kayıtlı ve de kayıt altına alınamamış suç oranlarının artması; suç mağdurlarına yönelik adlî, tıbbî, sosyal ve ekonomik yardımların yetersizliği gibi sorunlar mağduriyet kaygısını daha da artırmaktadır. (Bahar, 2006).

Sosyal ve politik ajandamızın büyük problemlerinden birisi olarak kabul edilmesi gereken suç korkusu "bir suça ya da kişinin suç ile ilişkilendirdiği sembollere karşı geliştirdiği bir duygusal korku veya endişe reaksiyonu" olarak tarif edilebilir (Ferraro, 1995).

Suç korkusu, daha önce mağdur olan kişilerde olduğu gibi, hiç mağdur olmadığ1 halde mağdur olabileceği endişesi yaşayan kişilerde de görülmektedir (Bahar, 2006).

Cinsiyet farklılıkları suç korkusu literatüründe en çok karşılaşılan değişken olarak dikkati çekmektedir. Kadınların genel olarak suç mağduru olmaktan erkeklere nazaran daha çok korktuğu, buna ek olarak ağır şiddet içerikli suçlarda bu korkunun çok daha fazla arttığı görülmüştür (LaGrange ve Ferraro, 1989). Özaşçlar (2006) tarafından yapılan bir çalışmada, kadınların suç korkusu düzeyi erkeklerden daha yüksek bulunmuştur. Kadınların erkeklere göre daha fazla endişelenmesinin nedenleri olarak kendilerini daha az savunabilecekleri hissi, kendilerine duydukları güveni daha az bir şekilde algılamaları, durumu olduğundan daha olumsuz algılamaları ve kendilerinin ve sosyal çevrelerinin bir suçun mağduru olabilmesi düşüncesinin daha yüksek olması gösterilmiştir (Jackson, 2009). Goodwin ve ark.nın (2005) gerçekleştirdikleri bir çalışmanın bulguları, terör mağduru olma olasılığı konusunda kadınların erkeklere göre daha fazla endişe duyduklarına ve terörizmi daha fazla tehdit olarak algıladıklarına işaret etmektedir.

Cinsiyetle birlikte suç korkusu literatüründeki bir diğer önemli değişkenin yaş olduğu görülmektedir. Literatürde yapılan araştırmadan 
çıkan sonuçlar genelde yaşın artmasıyla bireylerin daha çok korktuklarını göstermiştir (Hale, 1996).

Suç korkusu, hem bireylerin yaşam kalitelerini hem de toplumu olumsuz yönde etkileyen önemli bir sosyal sorundur (Franklin ve ark., 2008; Liska ve ark., 1988; Taylor ve Hale, 1986). Birey bazından bakıldığında suç korkusunun endişeye, güvensizliğe, memnuniyetsizlik ve tatminsizliğe, yabancılaşmaya ve psikolojik bozukluklara neden olduğu görülebilmektedir (Miceli vd., 2004). Maslow'un (1943) ihtiyaçlar piramidinde güvenlik ihtiyacl, fizyolojik ve biyolojik ihtiyaçlardan hemen sonra gelen en temel ihtiyaçtır. Dolayısıyla, güvenlik gibi temel bir ihtiyaç karşılanmadan insanların daha üst seviyedeki ihtiyaçlara yönelmesi mümkün olmaz zira güvenlik kaygısı yaşayan bir insanın tek arzusu güvenliğini sağlayabilmek için çabalamaktır (Maslow, 1943).

Her ne kadar Durkheim suçun kaçınılmaz, normal, zorunlu hatta halkta dayanışmaya yol açtığını ileri sürmekteyse de, suç korkusu, yabancılardan korkmayı, içe kapanmayı, dolayısıyla toplumsal birliği ve resmî olmayan kontrol mekanizmasını zayıflatır (Akıncı-Sokullu, 2002). Tüm bu göstergeler, toplumda güvenin azaldığını ve insanların birbirine daha da yabancılaştığını göstermektedir (Bahar, 2006).

Güvenlik kavramının en çok ele alındığg ve tartışıldığı alan terörle mücadele ve yöntemleridir. Terörle mücadelede amaçlardan biri de terörün yarattığ 1 tahribatın engellenmesi ve giderilmesidir. Bu tahribat sadece yol açtığı can ve mal kaybıyla sınırlı değildir. Aslında onu tehlikeli kılan yarattığ 1 psikolojik ve sosyal etkisidir (Ergil, 1992).

Terör kişilerin yaşam hakkını ve güvenliğini tehdit eden çok yönlü bir eylemdir. Terör sözcügü kelimenin etimolojik kökeninden de anlaşılacağ1 gibi "korkutma" esaslı bir fiildir. Lâtince kökenli "terrere" sözcügünden türemiştir (Wilkinson, 1974); "korkudan titretmek" ve "dehşete düşürmek" anlamına gelmektedir (Ergil, 1980).

Terörizm, genelde sembolik nitelikteki kurbanların ardındaki seyirci kitleyi etkilemeyi amaçlayan bir suç eylemidir (Tavas, 1999). Teröristik şiddet bu eylemleri gerçekleştirirken doğası gereği hedeflerini rasgele seçmektedir. Hiç kimse sıradaki kurbanın kendisi olmayacağından emin olamamaktadır (Wilkinson, 2002).

Terörist saldırılar sonrası yapılan çalışmalar değerlendirildiğinde; terörizmin kitleler üzerinde en yüksek psikolojik etkiye neden olabilecek 
şekilde tasarlanan bir savaşım biçimi olarak adlandırıldığı görülmektedir (Everly ve Mitchell 2001).

Terörizmin yarattığ1 pek çok psikolojik etki mevcuttur. Zira sivillere yönelik her türlü şiddet, maruz kalan ya da tanık olanlarda ciddi ruhsal sorunlara yol açabilmektedir. Özellikle de ölüm tehdidi, ölüm tehlikesi, ölümle yüzleşme her insanda şiddetli bir kaygıya yol açar (Candansayar, 2002). Terör olayları sonrasında da insanlar karşılaştıkları ölüm tehlikesi sonucunda yaşadıkları korkular sebebiyle bir takım travmalar yaşayabilmektedirler. Bunlardan başlıca ikisi "Akut Stres Bozukluğu" ve “Travma Sonrası Stres Bozukluğu”dur (Mühürcüoğlu, 2010).

Türk Psikologlar Derneği ve Türk Kızılayı işbirliği ile oluşturulmuş olan broşürde; terör olaylarının, insan eliyle yaratıldıkları için kişilerde kızgınlık, yaşama karşı güvensizlik ve hayatın anlamını sorgulama gibi bazı tepkilere neden olabileceğine değinilmiştir. Bununla birlikte terör olayını yaşamış kişilerde;

- Şok, korku, öfke, suçluluk, kaygı, çaresizlik ve umutsuzluk (duyguların hepsi yaşanabileceği gibi bir kısmı da görülebilir),

- Gerginlik, yorgunluk, uyku sorunları, yeme bozuklukları, kalp atışlarında düzensizlik ve ani irkilmeler,

- Huzursuzluk, güvensizlik, kendini reddedilmiş ya da yalnız hissetme, aşırı yargılayıcı ve suçlayıcı olma, her şeyi kontrol altında tutma isteği, çevreye ve olaylara yönelik ilgide azalma,

- Olayla ilgili görüntülerin sürekli akla gelmesi, olayı hatırlatan en ufak şeylerin kişiyi o ana götürülmesi, zihin sürekli bunlarla meşgul olduğundan başka bir işe yönelmekte ve karar vermede zorluklar yaşanabilir (Gökler ve Yilmaz, 2004).

Terörizmin toplumsal etkilerine bakıldığında ise devlet ve kurumlarına karşı güvensizlik, çevresel emniyet sorunu ve toplumun birbirine karşı yabancılaşması karşımıza çıkmaktadır (Tavas, 1999; Mühürcüoğlu, 2010). Savaştan farklı olarak terörizm saldırılarının belirsizliği ve sivil halkı hedef alması toplumdaki güven duygusunu kıran en büyük unsurdur (Demirli, 2011).

Dikkatle incelendiğinde terör eylemleri, yalnızca hedef alınan ve zarar verilen kişilerle, onların yakın çevresini etkilemez. Terör, toplumda her an "ben, ailem ya da bir yakınım kurban olabilir" korkusu yaratmaktadır 
(Candansayar, 2002). Özellikle belirli bir yerinin ya da belirli bir zamanının olmaması, terörizmin insanlar üzerinde yarattığı dehşetin derecesini daha da artırmaktadır (Yeniçeri ve Dönmez, 2008).

Laughter'e (2005) göre, medya tarafından oluşturulan imajlar da insanların terörizm algısını şekillendirmektedir. Terörist bir saldırı gerçekleştiği zaman medyanın bunu yansıtma şekli halkın terörizm korkusunu etkiler. Olayın ardından devlet tarafından alınan tedbirlerin de terör algısı üzerinde etkisi bulunmaktadır.

Bu bağlamda uluslararası bir tehdit olan terörün fiziksel tahribatının yanında psikolojik ve sosyolojik etkisinin de incelenmesi gerektiği bir ihtiyaç olarak karşımıza çıkmaktadır.

\section{Gereç ve Yöntem}

Araştırmanın evrenini, İstanbul'da bir vakıf üniversitesinin Fen-Edebiyat Fakültesine bağlı lisans programlarında öğrenim gören 970 üniversite öğrencisi oluşturdu. Öğrencilerin terör mağduru olma korkusu düzeylerinin saptanması amacıyla yapılan bu araştırmanın örneklemini, evreni belli örneklem hesabına göre (\%95 güven aralığı ve \% 5 hata payı) 276 üniversite öğrencisi oluşturdu.

Bu araştırmanın yapılması için İstanbul Yeni Yüzyıl Üniversitesi Etik Kurulunun 25.09.2017 tarih ve 2017/7 say1l toplantı sonucunda onay alınmıştır. Veri toplama aşamasında anket, araştırmaya gönüllü olarak katılmayı kabul eden öğrencilere uygulanmıştır. Anket uygulanmadan önce araştırmaya katılımın gönüllü olduğu, verdikleri cevapların gizli kalacağı, araştırmanın başlangıcında, ortasında ya da sonununda herhangi bir yaptırıma uğramadan araştırmadan çekilebilecekleri hakkında öğrencilere bilgi verilmiştir. Tüm öğrenciler araştırmaya gönüllü olarak katılmıştır. Öğrencilerin anketi cevaplamaları yaklaşık olarak 10 dakika sürmüştür. 350 kişiye anket formu verilmiş 306 adet geri dönüş sağlanmıştır. Formların 30'u eksik ya da hatalı olduğu için değerlendirme dışı bırakılmış olup değerlendirmeye alınan toplam 276 kişidir.

Araştırma verileri, araştırmacılar tarafından oluşturulan anket formu kullanılarak 01.10.2017 - 31.10.2017 tarihleri arasında toplanmıştır. Oluşturulan bu formda ilk olarak üniversite öğrencilerini tanımlayıcı bilgilere (yaş, cinsiyet, medeni durum, kiminle birlikte yaşadığı) yer verilmiş, 
ikinci olarak terör ve suç korkusu ile ilgili alanyazından elde edilen bilgilerden yararlanılarak oluşturulan sorulara yer verilmiştir. Terör ve mağdur olma korkusu ile ilişkili, seçenekleri "tamamen katılıyorum"dan "hiç katılmıyorum"a doğru giden beşli likert tip niteliğinde toplam 23 madde yer almaktadır.

Araştırma verilerinin değerlendirilmesinde basit tanımlayıcı istatistiksel değerlerin hesaplanmasından yararlanılmıştır.

\section{Bulgular}

Çalışmaya katılanların \%71,4'ü kadın, \%28,6'sı erkektir. Çalışmaya katılan katılımcların yaş ortalaması $21,92 \pm 3,77$, olup erkek katılımcıların yaş ortalaması 22,49 $\pm 3,08$, kadın katılımciların yaş ortalaması ise

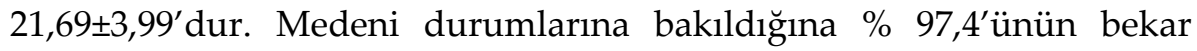
olduğu, \%45,3'ünün ailesiyle birlikte yaşadığı görülmektedir (Tablo 1).

Tablo 1. Katılımcıların Sosyo-demografik Bilgilerinin Dağılımı

\begin{tabular}{|l|c|}
\hline Sosyo-demografik bilgiler & Frekans \\
\hline Cinsiyet & \\
\hline Erkek & $\% 28,6$ \\
\hline Kadın & $\% 71,4$ \\
\hline Medeni durum & $\% 2,6$ \\
\hline Evli & $\% 97,4$ \\
\hline Bekar & \\
\hline Kiminle yaşadığı bilgisi & $\% 45,3$ \\
\hline Ailemle birlikte & $\% 2,5$ \\
\hline Akrabalarımdan biri veya birileriyle birlikte & $\% 29,3$ \\
\hline Yurtta & $\% 15,2$ \\
\hline Arkadaşlarımdan biri veya birileriyle birlikte & $\% 7,6$ \\
\hline Yalnız & \\
\hline
\end{tabular}

Son 1 yıl içinde herhangi bir terör eylemine maruz kalıp kalmadıkları sorulduğunda \% 13,4'ünün evet yanıtı verdiği, son 1 yıl içinde bir yakınları veya tanıdıklarının terör eylemi mağduru olup olmadığ sorulduğunda \% 36,6'sının evet yanıtı verdiği görülmüsstür.

Katılımcıların terör korkusuna yönelik anket sorularına cevaplarının dağılımı incelenirken "kesinlikle katılıyorum" ile "katılıyorum", "kesinlikle katılmıyorum" ile "katılmıyorum" cevaplarının frekansları birlikte 
değerlendirilmiştir.

Tablo 2. Katılımcıların Terör Korkusuna Yönelik Anket Sorularna Cevaplarının Dă̆ılımı

\begin{tabular}{|c|c|c|c|c|c|}
\hline Sorular & 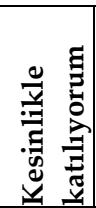 & 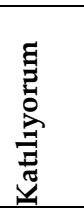 & 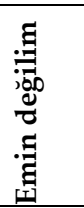 & 竞 & 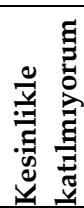 \\
\hline $\begin{array}{l}\text { 1.Yaşanan terör olaylarının } \\
\text { yaşantıma" olündelik } \\
\text { düşünüyorum. }\end{array}$ & 66,7 & 21,0 & 6,5 & 3,6 & 2,2 \\
\hline $\begin{array}{l}\text { 2. Yaşanan terör olayları nedeniyle toplu } \\
\text { taşıma araçlarını daha az kullanmaya } \\
\text { çalışıyorum. }\end{array}$ & 35,9 & 8,1 & 14,5 & 23,9 & 7,6 \\
\hline $\begin{array}{l}\text { 3.Yaşanan terör olayları nedeniyle AVM, } \\
\text { Sinema, Eğlence mekanları gibi kalabalık } \\
\text { yerlere daha az gitmeye çalışıyorum. }\end{array}$ & 38,0 & 27,5 & 12,3 & 13,8 & 8,3 \\
\hline $\begin{array}{l}\text { 4. Yaşanan terör olayları nedeniyle stadyum, } \\
\text { meydan (Taksim, Kızılay vs.) gibi açı ve } \\
\text { kalabalık yerlere daha az gitmeye } \\
\text { çalışıyorum }\end{array}$ & 45,7 & 27,5 & 9,4 & 10,5 & 6,9 \\
\hline $\begin{array}{l}\text { 5.Yaşanan terör olayları nedeniyle resmi ku- } \\
\text { rumlara daha az gitmeye çalışıyorum } \\
\text { (Adliye, Emniyet, Belediye vs.) }\end{array}$ & 33,3 & 18,8 & 15,6 & 0,7 & 11,6 \\
\hline $\begin{array}{l}\text { 6.Mecbur kalmadıkça tek başıma dışarı } \\
\text { çıkmamaya çalışıyorum. }\end{array}$ & 20,3 & 15,2 & 11,6 & 26,1 & 26,8 \\
\hline $\begin{array}{l}\text { 7.Kendimi evimin olduğu yerde güvende } \\
\text { hissediyorum. }\end{array}$ & 37,7 & 24,3 & 15,2 & 12,0 & 10,9 \\
\hline $\begin{array}{l}\text { 8.Kendimi okulumun/işimin olduğu yerde } \\
\text { güvende hissediyorum. }\end{array}$ & 18,5 & 26,1 & 1,7 & 17,8 & 15,9 \\
\hline $\begin{array}{llll}\text { 9.Terör saldırılarına } & \text { karşı } & \text { Polisin } \\
\text { vatandaşları } & \text { korumasına } & \text { yönelik } \\
\text { güven }\end{array}$ & 24,6 & 18,8 & 21,4 & 18,5 & 16,7 \\
\hline $\begin{array}{l}\begin{array}{l}\text { 10.Terör saldırılarına } \\
\text { vatandaşları korumısı }\end{array} \text { Askerin } \\
\text { duyuyorum. }\end{array}$ & 7,5 & 21,4 & 20,3 & 15,6 & 15,2 \\
\hline $\begin{array}{l}\text { 11.Terör saldırılarına karşı Devletin } \\
\text { vatandaşları korumasına yönelik güven } \\
\text { duyuyorum. }\end{array}$ & 17,4 & 11,2 & 17,0 & 17,4 & 37,0 \\
\hline $\begin{array}{l}\text { 12.Güvenliğimi sağlamak için silahlanmam } \\
\text { gerektiğini düşünüyorum. }\end{array}$ & 15,6 & 12,3 & 14,5 & 26,4 & 31,2 \\
\hline
\end{tabular}




\begin{tabular}{|l|c|c|c|c|c|}
\hline $\begin{array}{l}\text { 13.Yaşanan terör olayları nedeniyle ülkenin } \\
\text { geleceği konusunda endişeliyim. }\end{array}$ & 75,4 & 9,8 & 6,2 & 4,3 & 4,3 \\
\hline $\begin{array}{l}\text { 14.İmkanım olsa sadece güvenlik nedeniyle } \\
\text { başka bir şehre taşınmayı düşünürüm. }\end{array}$ & 34,1 & 11,2 & 16,7 & 19,2 & 18,8 \\
\hline $\begin{array}{l}\text { 15.İmkanım olsa sadece güvenlik nedeniyle } \\
\text { başka bir ülkeye taşımmayı düşünürüm. }\end{array}$ & 48,6 & 14,9 & 9,8 & 8,7 & 18,1 \\
\hline $\begin{array}{l}\text { 16.Terör eylemlerini yapan kişilerin idam } \\
\text { cezası alması gerektiğini düşünüyorum. }\end{array}$ & 44,6 & 13,8 & 16,7 & 9,1 & 15,9 \\
\hline $\begin{array}{l}\text { 17.Kendimin terör mağduru olacağı endişesi } \\
\text { yaşıyorum. }\end{array}$ & 43,5 & 29,3 & 11,2 & 9,1 & 6,9 \\
\hline $\begin{array}{l}\text { 18.Yakınlarımın terör mağduru olacağı } \\
\text { endişesi yaşıorum. }\end{array}$ & 49,3 & 26,1 & 9,8 & 7,6 & 7,2 \\
\hline $\begin{array}{l}\text { 19.Ailem benim terör eylemi mağduru } \\
\text { olacağım endişesi yaşıyor }\end{array}$ & 46,4 & 23,6 & 11,2 & 10,9 & 8,0 \\
\hline $\begin{array}{l}\text { 20.Arkadaşlarım/yakınlarım benim terör } \\
\text { eylemi mağduru olacağım endişesi yaşıor. }\end{array}$ & 40,6 & 25,7 & 12,0 & 12,3 & 9,4 \\
\hline $\begin{array}{l}\text { 21.Terör olayları ile ilgili duyduğum } \\
\text { rivayetler endişelenmeme neden oluyor. }\end{array}$ & 48,2 & 25,7 & 11,2 & 6,5 & 8,3 \\
\hline $\begin{array}{l}\text { 22.Sosyal medyanın terör mağduru olma } \\
\text { korkusunu arttırdığını düşünüyorum. }\end{array}$ & 33,0 & 26,8 & 18,8 & 9,8 & 11,6 \\
\hline $\begin{array}{l}\text { 23.Televizyon, gazetelerin terör mağduru } \\
\text { olma korkusunu arttırdığını düşünüyorum. }\end{array}$ & 33,3 & 24,6 & 19,2 & 10,5 & 12,3 \\
\hline
\end{tabular}

Katılımcıların \%87,7'si yaşanan terör olaylarının gündelik yaşantılarına olumsuz etkisi olduğunu düşünmektedir. \%65,5'i AVM, Sinema gibi kapalı ve kalabalık mekanlara, \%73,2'si stadyum, meydan gibi açık ve kalabalık mekanlara daha az gitmeye çalıştığını belirtmektedir. Yaşanan terör olayları nedeniyle ülkenin geleceği konusunda endişeli olduğunu belirtenlerin oranı $\% 85,2$ 'dir. Sadece güvenlik nedeniyle başka şehre taşınmayı düşünenlerin oranı \% 45,3 iken, başka ülkeye taşınmayı düşünenlerin oranının $\% 63,5$ olduğu görülmektedir. Katılımcların $\% 72,8^{\prime}$ i kendisinin, \%75,4'ü yakınlarının terör eylemi mağduru olacağ 1 endişesi yaşadığını ifade etmektedir. Ayrıca \% 58,4'ü terör eylemi gerçekleştirenlerin idam cezası alması gerektiğini düşünmektedir. Terör saldırılarına karşı vatandaşları korumasına yönelik polise karşı güven duyanların oranının $\% 43,4$, askere $\% 48,9$, devlete ise $\% 28,6$ olduğu ve katılımcıların \%27,9'unun bireysel olarak silahlanması gerektiğini düşün- 
düğü görülmüş̧tür. Terör mağduru olma korkusunu sosyal medyanın arttırdığını düşünenlerin oranı $\% 59,8$ iken, televizyon ve gazetelerin arttırdığını düşünenlerin oranı da \%57,9'dur (Tablo 2).

\section{Tartışma}

Son yıllarda küresel terörizmin tırmanması ile birlikte Türkiye de terör olaylarından giderek daha fazla etkilenmektedir. Yaşanan bu terör olaylarının toplum içinde yarattığı güvensizlik duygusu, kişileri savunmasız bırakması, ölüm ve sakatlık gibi durumlarla karşı karşıya gelmeleri kişilerde psikolojik travmalara neden olmaktadır (Hunter, 1978; Sipahi, 2016).

Terör eylemleri, sadece mağdur olan kişilerde değil hiç mağdur veya tanık olmamış kişilerde de yarattığı mağdur olma korkusu nedeniyle bireysel olmaktan çıkıp toplumsal düşünme ve yaşayışı olumsuz yönde etkileyen bir durumdur (Kul, 2012; Boscarino, 2003). Çalışmamızda da katılımcıların sadece \%13,4'ü bir terör olayına maruz kaldığını belirtirken; yaşanan terör olaylarının gündelik yaşantılarına olumsuz etkisi olduğunu düşünenlerin oranı $\% 87,7^{\prime}$ dir. Terör olayları nedeniyle AVM, Sinema gibi kapalı ve kalabalık mekanlara ve stadyum, meydan gibi açık ve kalabalık mekanlara daha az gitmeye çalıştığını belirtenlerin oranı terör mağduru olan kişilere göre oldukça yüksektir ( $\%$ 65,5; \% 73,2). Sipahi tarafından 2016 yılında yapılan çalışmada da terör saldırısından korkanların oranı \%78 olarak tespit edilirken, terör saldırısına uğrama korkuları 1 ile 5 arasında değerlendirilen katılımcıların korku düzeyleri 4,07 olarak tespit edilmiştir (Sipahi, 2016).

Maslow'un ihtiyaçlar hiyerarşisinde tanımlanan temel insan gereksinimlerinden biri güvenliktir. Aynı zamanda yaşam memnuniyetini gösteren bir ölçüttür. Terör olayları temel bir gereksinim olan bu güvenlik duygusunu zedeleyerek toplumda güvensizlik duygusu yaratmaktadır. Amerika' da yapılan kamuoyu yoklamalarında terör eylemlerinden sonra, vatandaşlarını terör eylemlerinden koruma konusunda $\mathrm{ABD}$ hükümetine duyulan güvenin azaldığ 2001 yılında \% 88 olan güven oranının 2015 yılında \% 55'e gerilediği görülmüştür (Gallup, 2015). Bizim çalışmamızda terör saldırılarına karşı devletin vatandaşları korumasına yönelik güven duyanların oranı \% 28,6'dır. Katılımciların \%33,7'si de kendini okulunun 
veya işinin olduğu yerde güvende hissetmediğini belirtmiştir. Buna emin olmayanların oranı da eklendiğinde katılımcıların \% 55,4'ü iş veya okulda bulunduğu sürede kendini güvende hissetmemektedir.

Suç korkusu bireysel silahlanma gibi şiddet riski taşıyan davranışları pekiştime riski taşımaktadır. Warr (1992), diğerleri için korku duyduğunu ifade eden kişilerin önlem amaçlı silah sahibi olma oranlarının korku duyduğunu ifade etmeyenlerin yaklaşık üç katı olduğunu göstermiştir. Bizim çalışmamızda da katılımcıların \% 27,9'unun bireysel olarak silahlanması gerektiğini düşünmesi bu durumun azımsanmayacak bir bulgu olduğunu işaret etmektedir. Ayrıca katılımcıların \% 58,4'ünün terör eylemlerini yapan kişilerin idam cezası alması gerektiğini düşünmesinin, insanlar için yaşamsal bir tehdidin ortadan kaldırılması anlamına geldiğini söylemek mümkündür.

Terör olayları sonrasında ortaya çıkan toplumsal algı sadece olayın yaşandığı alan veya olaya maruz kalan kişilerle sınırlı değildir. Küreselleşme süreci ve bu süreci hılandıran medya ve iletişim teknolojilerindeki yenilikler terör olaylarının daha geniş kitleleri etkilemesine, terör mağduru olanların haricindeki kişilerin de terörizm faaliyetlerine maruz kalmasına neden olmuştur (Muş, 2015; Tuncay, 2018). 11 Eylül saldırısı sonrasında Boscarino ve arkadaşları tarafından yapılan çalışmalarda Amerikalılar için terör eylemlerinin gerçekleşme ihtimalinin ciddi bir psikolojik etkiye sahip olduğu tespit edilmiştir ( Boscarino, 2003; Boscarino, 2006). Çalışmamızda da katılımcıların \%72,8'i kendisinin, \%75,4'ü yakınlarının terör eylemi mağduru olacağı endişesi yaşadığını ifade etmiştir. Sosyal medya ile gazete ve televizyonların terör mağduru olma korkusunu arttırdığı ile ilgili ifadeye ise katılımcılar sırasıyla \% 59,8 ve $\% 57,9$ oranında katıldıklarını belirtmişlerdir.

Literatürdeki çalışmalara bakıldığında kadınların erkeklere göre daha fazla suç mağduru olma korkusu taşıdıkları görülmüştür. Bizim çalışmamızın örnekleminin de \% 71,4'ünün kadın katılımcılardan oluşması ile birlikte değerlendirildiğinde terör mağduru olma korkusunun yüksek çıkması kaçınılmazdır. Ayrıca bu sonucun toplumsal cinsiyet algısı ile de ilişkili olabileceğini de düşündürtmektedir. 


\section{Sonuç}

Araştırmanın sonuçları; katılımcıların terör eylemine maruz kalma endişesi yaşadıklarını, ülkenin geleceği konusunda endişe duyduklarını, buna istinaden bulundukları şehri, hatta ülkeyi terk etme eğilimi içinde olduklarını, gündelik yaşantılarının olumsuz yönde etkilendiğini ve sosyal yaşamdan çekildiklerini göstermektedir. Ayrıca medyanın terör mağduru olma korkusunu etkilediği, devlet ve kurumlarına karşı güvensizliğin de oluştuğunu söylemek mümkündür.

Çalışmanın sonuçları, mağdur olma korkusu kapsamında terörü ele almış olması ve uluslarası bir tehdit olan terörün psikolojik ve sosyolojik etkilerini incelemesi açısından önemlidir.

$\mathrm{Bu}$ araştırmanın örneklemini sadece bir üniversitenin öğrencileri oluşturduğundan konunun daha geniş örneklemlerle araştırılması, farklı demografik bilgilerle karşılaştırmalar yapılması gerektiği düşünülmektedir. Ayrıca bizim çalışmamızda kadın katılımcıların daha fazla olmasının sınırlılığı göz önüne alındığında kadın ve erkek katılımcıların benzer oranlarda temsil edildiği çalışmalara ihtiyaç olduğu düşünülmektedir.

Literatürde yapılan araştırmadan çıkan sonuçlarda genelde yaşın artmasıyla bireylerin daha çok korktuklarını göstermiştir. Bu bağlamda yaş değişkeni göz önüne alınarak terör mağduru olma korkusunun araştırılması gerektiği, ayrıca bu konu kapsamında yapılacak çalışmalarda terör mağduru olma korkusunun yanı sıra kişilik özellikleri, özgüven, toplumsal cinsiyet algısı gibi etkileyebilecek nedenlerin de araştırılması gerektiği düşünülmektedir.

Sonuç olarak terör mağduru olma korkusu, evrensel düzeyde, yaşamı etkileyen bireysel ve toplumsal önemli bir sorundur. Söz konusu kavrama ilişkin daha derin bir bakış açısı kazanmada psikolojinin ve sosyolojinin sunacağı büyük katkılar olduğuna inanmaktayız. 
EXTENDED ABSTRACT

\title{
The Evaluation of The Fear of Being Victims of Terror at University Students: The Example of Istanbul
}

\author{
$*$ \\ Burcu Türk - Nurcan Hamzaoğlu \\ Haliç University - İstanbul Yeni Yüzyıl University
}

The fear of crime began to rank among the most important social problems within modern societies. The fear of crime is an important social problem, which negatively effects not only the life quality of individuals but also the society. When looking at fear of crime on an individual basis, it can be seen that it leads to anxiety, insecurities, dissatisfactions and discontentment, alienations and psychological disorders. The fight against terrorism and its methods is the area in which the concept of terror is most approached and discussed.

Terror is a multi-faceted action that threatens the right to life and security of persons. Especially the fact that it does not have a specific place or time, further increases the degree of horror that terrorism creates on people. Terrorist actions do not only influence the targeted and harmed people and immediate circle. Terror creates the fear of "Either me, my family or my close relatives/friends can be a victim" in the society (Candansayar, 2002).In addition to the physical destruction of terror, which is an international threat, psychological and sociological effects of it must be examined. A questionnaire was applied to 276 university students in order to determine the level of the fear of being a victim of terror. $71.4 \%$ of the participants were female and $28.6 \%$ were male. The age average of the whole participants is $21.69 \pm 3.77$, the male participants is $22.49 \pm 3.08$ and female participants is $21.69 \pm 3.99$. When looking at their marital status, it is observed that $97.4 \%$ is single and $45.3 \%$ is living with their family. $87.7 \%$ of the participants think that the terrorist events have a negative effect on their daily lives. $65.5 \%$ of the participants stated that they try going less to 
closed and crowded places like shopping malls, movie theaters; $73.2 \%$ to open places like stadiums, squares. The ratio of those who stated that they are worried about the future of the country due to the terrorist incidents is $85.2 \%$. The rate of those who think about moving to another city for security reasons is $45.3 \%$ to another country, on the other hand, is $63.5 \%$. The rate of those who stated that they have worries about themselves being a victim of terrorist acts was $72.8 \%$ and their relatives being a victim was $75.4 \%$. Moreover, $58.4 \%$ of the participants believe that the people who carried our terrorist actions should get the death penalty. The ratio of the participants that have confidence in the police force for their protection against terrorist attacks is $43.4 \%$, in military $48.9 \%$ and in the state is $28.6 \% .27 .9 \%$ of the participants think that individual armament is necessary. While $59.8 \%$ of the participants think that social media increases the fear of being victim of terror, $57.9 \%$ thinks TV and newspapers enhances the fear.

The results of the research show that participants live with the anxiety of exposure to terrorist actions, they are anxious about the future of the country, due to this they have a tendency to leave their city or even the country, their daily lives are effected negatively, and they are retreated from social life. In addition, it is possible to say that media affects the fear of being a victim of terror and there emerged distrust against the state and its institutions. Since the sample of this research is made up of only one university's students, the subject should be studied with wider samples and comparisons should be made with different demographic information. Besides when the limitedness of the more number of female participants in our study is taken into considerations, it is believed that studies with similar ratios of male and female participants is needed.

The results of the researches made in literature show that individuals fear more with aging. In this context it is needed to investigate the fear of being a victim of terror through considering the age factor. In addition, besides the fear of being a victim of terror, reasons like personality characteristics, self-confidence and gender perception that could be effective should researched in studies, which will be made in this context.

The results of the study are important in terms of addressing terror within the context of the fear of being victims and examining the psychological and sociological effects of it, which is an international threat. As a 
result, the fear of being a victim of terror, is an important individual and societal problem that affects lives on a universal basis. We believe that psychology and sociology can make important contributions in gaining a deeper perspective with regards to the concept.

\section{Kaynakça / References}

Akıncı-Sokullu, Füsun. (2002). Kriminoloji. İstanbul: Beta Yayım Dağıtım A.Ș.

Bahar, H. İ. (der.) (2006). Suç mağdurları. Ankara: Adalet Yayınevi.

Boscarino, J. A., Figley, C. R., ve Adams, R. E. (2003). Fear of terrorism in New York after the September 11 terrorist attacks: Implications for emergency mental health and preparedness. International journal of emergency mental health, 5(4), 199-209.

Boscarino, J. A., Adams, R. E., Figley, C. R., Galea, S., ve Foa, E. B. (2006). Fear of terrorism and preparedness in New York City 2 years after the attacks: implications for disaster planning and research. Journal of public health management and practice: JPHMP, 12(6), 505-513.

Candansayar, S. (2002). Terörizm ve psikiyatri. Cemal Güzel (der.). Silinen Yüzler Karşısında Terör. (ss. 374-414). Ankara: Ayraç Yayınevi.

Demirli, A. (2011). Terörizm, psikososyal etkileri ve müdahale modelleri. Türk Psikolojik Danışma ve Rehberlik Dergisi, 4(35), 66-76.

Ergil, D. (1980). Türkiye'de terör ve şiddet (1.baskı). Ankara: Çağ Yayınlar1.

Ergil, D. (1992). Uluslararası terörizm. Ankara Üniversitesi SBF Dergisi, 47 (3), 139-143.

Everly G.S. Jr., Mitchell J.T. (2001) America under attack: The "10 Commandments" Of Responding To Mass Terrorist Attack. Int J Emerg Ment Health, 3, 133-135.

Ferraro, K. F. (1995). Fear of crime: Interpreting victimization risk. Albany: State University of New York Press.

Franklin, T. W., Franklin, C. A. ve Fearn, N. E. (2008). A multilevel analysis of the vulnerability, disorder, and social integration models of fear of crime. Social Justice Research, 21, 204-227. 
Gallup (2015). Trust in Government to protect against terrorism at new low. https://news.gallup.com/poll/187622/trust-government-protect-against-terrorismnewlow.aspx?g_source=link_NEWSV9\&g_medium=related_tile3\&g_campaign=item_187688\&g_content $=$ Trust $\% 2520 \mathrm{in} \% 2520$ Government $\% 2520$ to $\% 2520$ Protect $\% 2520$ Against $\% 2520$ Terrorism $\% 2520$ at $\% 2520$ New $\% 2520$ Low (Erişim tarihi: 13.12.2018).

Goodwin, R., Willson, M. ve Gaines, S. (2005). Terror threat perception and its consequences in contemporary Britain. British Journal of Psychology, 96, 389-406.

Gökler, I. ve Yılmaz, B. (2004). Terör olaylarının psikolojik etkileri ve başaçıkma yolları broşürü. Ankara: TC Kızılay Derneği ve Türk Psikologlar Derneği yayını.

Hale, C. (1996). Fear of crime: A review of literature. International Review of Victimology, 4, 79-150.

Hunter, A. (1978, November). Symbols of incivility: Social disorder and fear of crime in urban neighborhoods. In Annual Meeting of the American Criminological Society, Dallas.

Jackson, J. (2009). A psychological perspective on vulnerability in the fear of crime. Psychology, Crime and Law 15(4), 365-390.

Korkmaz, M. (2016) Türkiye'nin Doğu ve Güneydoğu Anadolu bölgelerinde görev yapan öğretmenlerin terör mağduru olma korkusu. (Yayınlanmamış doktora tezi) Kara Harp Okulu Savunma Bilimleri Enstitüsü Güvenlik Bilimleri Anabilim Dalı, Ankara.

Kul, M. (2013). Suçtan daha büyük suç korkusu. İstanbul: Yeniyüzyıl.

LaGrange, R. L., ve Ferraro, K. F. (1989). Assessing age and gender differences in perceived risk and fear of crime. Criminology, 27(4), 697720 .

Laughter, M. (2005). Us nuclear plants as terrorist targets", (Yayımlanmamış Yüksek Lisans Tezi), MIT.

Liska, A. E., Sanchirico, A. ve Reed, M. D. (1988). Fear of crime and constrained behavior: Specifying and estimating a reciprocal effects model. Social Forces, 66, 827-837.

Maslow, A. H. (1942). The dynamics of psychological security-insecurity. Journal of Personality, 10(4), 331-344. 
Miceli, R., Roccato, M. ve Rosato, R. (2004). Fear of crime in Italy: Spread and determinants. Environment and Behavior, 36(6), 776-789.

Muş, E., Can, A., ve Güçlü, İ. (2015). Terörün toplum ve sosyal hayata etkileri. Türkiye Klinikleri Journal of Forensic Medicine-Special Topics, 1(2), 5-14.

Mühürcüoğlu, E. (2010). Bombalı intihar saldırısı sonucu oluşan suç korkusu üzerine bir vaka incelemesi: Ulus-Anafartalar Çarşısı Örneği. (Yüksek lisans tezi). Hacettepe Üniversitesi Sosyal Bilimler Enstitüsü Sosyoloji Anabilim Dalı, Ankara.

Özaşçılar, M. (2006). Suç korkusu: İstanbul'da yaşayan 18-25 yaşarası üniversite öğrencilerinin mağdur olma riskleri hakkındaki görüşlerinin değerlendirilmesi. Yüksek Lisans Tezi. İÜ. Adli Tıp Enstitüsü, İstanbul.

Sipahi, E. B. (2016). Türkiye'de kent sakinlerinin suç korkuları üzerine bir araştırma. Journal of International Social Research, 9 (43). 2158-69

Tavas, T. (1999). Terörizm Bağlamında intihar saldırıları örnek olayı. Yüksek Lisans Tezi. Ankara Üniversitesi Sosyal Bilimler Enstitüsü, Ankara.

Taylor, R. B. ve Hale, M. (1986). Testing alternative models of fear of crime. Journal of Criminal Law and Criminology, 77, 151-189.

Tuncay, T., ve Akçay, S. (2018). Terörizmin psikososyal etkileri ve sosyal hizmet uzmanının rolleri. Toplum ve Sosyal Hizmet, 29(2), 307-334.

Wilkinson, P. (1974). Political terrorism. London.

Wilkinson, P. (2002). Terör ve terörizm: Kavramlar, özellikler ve tipoloji (Çev. Talip Kabadayı). Cemal Güzel (der.). Silinen Yüzler Karşısında Terör. (ss. 142-162). Ankara: Ayraç Yayınevi.

Yeniçeri, Z. ve Dönmez A. (2008). Terörizm ve terörist alg1sı: Silahı kimin tuttuğu ne kadar etkili? Türk Psikoloji Dergisi, XXIII(62), 93-103

Warr, M. (1992). Alturistic fear of victimization in households. Social Science Quarterly, 73, 723-736. 


\section{Kaynakça Bilgisi / Citation Information}

Türk, B. ve Hamzaoğlu, N. (2019). Üniversite öğrencilerinde terör mağduru olma korkusunun değerlendirilmesi: İstanbul örneği. OPUS-Uluslararası Toplum Araştırmaları Dergisi , 10(17), 176-193. DOI: 10.26466/opus.503138 